\title{
Supplementation disrupts the circannual rhythm of vitamin D: A retrospective analysis
}

\section{Destek tedavisi D vitamininin yullık ritmini bozar: Retrospektif bir analiz.}

(D) Özgür Aydın ${ }^{1}$

1) Kepez Devlet Hastanesi, Biyokimya Uzm. Dr., Antalya

İletişim adresi:

Uzm. Dr. Özgür Aydın

belozgur@hotmail.com
Geliş tarihi: 19/03/2020

Kabul tarihi: 11/08/2020

Yayın tarihi: 25/09/2020 


\section{Özet}

Giriş: D vitamini eksikliği dünyanın pek çok bölgesinde endemik kabul edilmektedir. Son y1llarda destek tedavisinin faydaları tedavinin yaygın olarak kabul görmesine neden olmuştur. Bu durumun D vitamini ve ilgili sistemlerin fizyolojik özelliklerinde bozulmalara neden olması beklenmelidir.

Yöntem: Laboratuvar bilgi sisteminden iki grup veri alındı. Birinci grup (Total Grup) Haziran 2018 Mayıs 2019 arasındaki tüm D vitamini test sonuçlarıdır. İkinci grup (Destek Tedavisi Grubu) D vitamini eksikliği tanısı ile takip edilen ve destek tedavisi alan hastaların D vitamini test sonuçlarıdır.

Bulgular: D vitamini test sonuçları aylık bazda analiz edildiğinde Destek Tedavisi Grubu median değerleri y1l boyunca Total Grup median değerlerinden yüksektir. Aylık veriler şekil olarak incelendiğinde Total Grupta gözlenebilen D vitamininin fizyolojik yıllık döngüsü Destek Tedavisi Grubunda bozulmuştur.

Tartışma ve Sonuç: Toplumda D vitamininin var olan her hastalığa iyi geldiğine dair yanlış bir inanç oluşmuştur. $\mathrm{Bu}$ durum dünya çapında $\mathrm{D}$ vitamini destek tedavisinin yaygın olarak kullanılması sonucunu doğurmuştur. $\mathrm{Bu}$ ölçekte müdahalelerin çalışmada saptandığı üzere yıllık döngü gibi D vitamininin fizyolojik özelliklerini bozan sonuçları olacaktır.

Anahtar Sözcükler: vitamin D, yan etkiler; tedavi, fizyoloji, normal değerler

\section{Summary}

Objectives: MPV and PDW are vascular complications markers and improved glycemic control levels are correlated those indicators in patients with type 2 Diabetes Mellitus. The aim of in this study, MPV and PDW levels were compared type 2 diabetic patients treated with oral antihyperglycemic agent and insulin.

Methods: This study was performed retrospectively on type $2 \mathrm{DM}$ patients who were admitted to Ankara Atatürk Training and Research Hospital. 118 randomly selected patients were divided into 3 groups that were non-diabetic (Group 1), who received OAD therapy (Group 2), and those who received insulin therapy (Group 3). HbA1c, MPV, PDW levels were collected, analyzed and compared with each other.

Results: MPV and PDW values were increased in type 2 DM patients compared to the control group (Group 2; $<<0.001$ and Group $3 \mathrm{p}$ $<0.001$, respectively). There was no statistically significant difference between MPV and PDW values in patients treated OAD and insulin therapy ( $p=0.736$ ve $p=0.360$ respectively). A statistically significant positive correlation was found between $\mathrm{HbA1} c$ values and MPV ( $p$ $<0.001)$ and PDW $(\mathrm{p}<0.001)$ values.

Conclusions: In our study, no significant difference was found between MPV and PDW values of patients using insulin and oad. Early initiation of conventional insulin therapy in patients with type 2 diabetes provides good glycemic control. Rational drug use in accordance with the guidelines; gains importance in treatment success. Skipping this factor may reduce the efficiency of other efforts in relation to rational treatment.

Key Words: Vitamin D, side effects, therapy, physiology, normal values

Alıntı Kodu: Aydın Ö. Destek tedavisi D vitamininin ylllık ritmini bozar: Retrospektif bir analiz

Jour Turk Fam Phy 2020; 11 (3): 108-115. Doi: 10.15511/tjtfp.20.00308. 


\section{Introduction:}

Vitamin D is a steroid molecule that has endocrine, paracrine and autocrine functions. Human skin is capable of producing adequate amounts of it by using internal sources. The energy transferred from solar ultraviolet $\mathrm{B}$ radiation is used to synthesize vitamin $\mathrm{D}$ via photochemical ring-opening and isomerization steps of the precursor molecule (7-dehydrocholesterol) localized in the human epidermis. Breaking and reforming chemical bonds require a specific intensity of energy that the angle between the local vertical of the sun at any given moment and the surface of the earth is a key environmental factor. By the way, the amount of vitamin D production largely depends on seasons and geographic latitude. People living in temperate regions of the world typically have a high vitamin D status in summer that last through autumn and lowest levels during winter as the skin is not able to synthesize Vitamin D because of seasonal variation in ultraviolet radiation exposure. ${ }^{(1,2)}$

Vitamin D insufficiency, as measured by serum 25-Hydroxyvitamin D (25(OH)D) levels, is considered endemic in many parts of the world. The literature on vitamin $\mathrm{D}$ demonstrates an association between deficits in vitamin $\mathrm{D}$ and a plethora of infectious, autoimmune and neoplastic conditions. ${ }^{(3-8)}$ As an inevitable consequence, majority of human population present nominee for supplementation therapy in order to treat or even prevent nearly every known human disease.

The aim of the study was to search the effect of supplementation therapy on the circannual rhythm of vitamin D. If such an impact is present hopefully, it may induce and inspire awareness on potential consequences of the large-scale artificial interference to the physiology of a steroid hormone with known and unknown roles in human metabolism.

\section{Methods:}

Retrospective data including age, gender, electronic prescriptions and laboratory test results were obtained from the laboratory information system electronic medical records at Antalya Kepez Public Hospital. Ethics approval was obtained from Antalya Education and Research Hospital prior to data collection (2019/216, 17/19). Written patient consent was not requested and patient information was anonymized and de-identified prior to analysis.

First group of data (Total group) included all $25(\mathrm{OH}) \mathrm{D}$ test results of patients admitted to any outpatient clinics of the hospital between June 2018 and May 2019. All validated 25(OH)D results were included without any exceptions. In the second group (Supplementation group), patients were filtered as follow-up outpatients admitted to the Internal Medicine Outpatient Clinic between January 2019 and August 2019. Ten consecutive patients with an ICD code diagnosis of hypovitaminosis D were selected randomly in every Wednesday of a week in eight months. Each patient was retrospectively searched for electronic prescriptions and 25(OH)D test results. All electronic prescriptions were reviewed for drugs of vitamin D supplementation and 25(OH)D test results were also recorded. Total Group included every patient regardless of using supplementation. Supplementation Group was composed of 320 randomly selected patients with more than 1 electronic prescription of medical preparations of vitamin D. Both of the groups could include multiple test results of a single patient.

Data were analyzed using IBM SPSS 21 and Microsoft Excel 2013 to calculate results and create graphics. 


\section{Results:}

In the Total Group there were $53.97225(\mathrm{OH}) \mathrm{D}$ test results between June 2018 and May 2019. Of these $37.910(70,24 \%)$ were obtained from female, $16.062(29,75 \%)$ were obtained from male patients. Mean age was 40,6 years. Supplementation Group was composed of 320 patients: 258 female (80,62\%) and 62 male $(19,37 \%)$. Mean age was 41,92 years. Retrospective search presented a total of 965 elec tronic prescriptions in a mean duration of 8,75 months and a total of $1.12325(\mathrm{OH}) \mathrm{D}$ test results that belonged to these randomly selected 320 patients (3 electronic prescriptions per patient and 3,525(OH)D test results per patient).

The number and medians of test results of both groups were presented month by month (Table). In both groups the lowest values were detected in January and a peak value in September. Supplementation Group showed higher values in all months in accordance of profit of supplementation. In both groups, there were a parallel incline in February, March and April with a nearly steady gap in favor of the Supplementation Group. In May, both groups showed a decline. In Total Group the decline was relatively smooth $(15,84 \mathrm{ng} / \mathrm{mL}$ in April, $15,28 \mathrm{ng} / \mathrm{mL}$ in May) while the decline in Supplementation Group was much more marked $(24,21 \mathrm{ng} / \mathrm{mL}$ in April, 20,40 ng/mL in May). The period between May and October was quite different in both groups: the Total Group conserved the slope to peak in September while Supplementation Group could not catch the 25(OH)D median level of April until August. The levels in November and December differed completely between groups as Total Group showed a steady decline to complete the circannual rhythm while Supplementation Group showed a prominent incline.

\section{Conclusions:}

According to the reference normal values (30-50 ng/ $\mathrm{mL}$ ), we have a nation totally suffering from deficiency of the hormone named as vitamin $\mathrm{D}$; responsible from maintenance of calcium homeostasis and many other systems known or not yet known. ${ }^{(9)}$ Largest organ of the human body, the skin is very capable of producing adequate amounts of the hormone with the aid of the sun shining bright and strong in the sky especially in summer. However, social behaviors like closed clothing or city life are accused of diminished production as a result of blockade of direct contact between the skin and sunlight. Accordingly, nearly any patient admitting to a hospital is a nominee for supplements unless he or she changes lifestyle. ${ }^{(9)}$

Considering the cutaneous exposure to sunlight as the major source of vitamin D, serum $25(\mathrm{OH}) \mathrm{D}$ concentration, as the determinant of vitamin D status, should show seasonal variation at mid-latitudes of the world. Expectedly, the seasonal variation in serum $25(\mathrm{OH}) \mathrm{D}$ concentration follows a cycle with the lowest levels at the end of the winter and the highest levels at the end of summer.

In the Figure which was created by comparing the $25(\mathrm{OH}) \mathrm{D}$ test results of the general patient population to the group of patients with prescribed vitamin D supplementation; the circannual rhythm was clearly visible in the Total Group neglecting a slight decrease in May, while the pattern was obviously corrupted in the Supplementation Group (Figure). A prominent feature in the Figure was the diversion in November and December where the physiologic decline in Total Group was opposed by an unexpected incline in Supplementation Group. The feature could be explained as an effect of supplementation considering the season of the year in Turkey. 
Both graphs showed sharp decline in January in midwinter followed by gradual increase to reach the peak in September as expected. Another prominent feature of the Figure was the decline in May. Although it appeared in both lines it differed quite a lot in the overall scene. Considering the whole figure, it seemed to be a somewhat unexpected shift in Total Group's line so that if it was omitted the Figure would best fit to represent a circannual rhythm. However in the Supplementation Group's line it looked like a crack in the general flow of the graph. The feature presented in both graphs but in an execrated manner in Supplementation Group. It might have been an indicator of supplementation rate in the general population. Total group was not searched for electronic prescriptions so the percentage of vitamin D supplementation in this group was unknown. This was a limitation to the study.

In 2018 Vurgun et al. published their research article about assessment of vitamin D deficiency levels in an adult population in Istanbul/Turkey. ${ }^{10}$ In their report 25(OH)D levels $(\mathrm{ng} / \mathrm{mL} ;$ mean $\pm \mathrm{SD})$ were presented as : $18,0 \pm 12,4$ in summer; $17,8 \pm 11,3$ in autumn; $20,8 \pm 13,5$

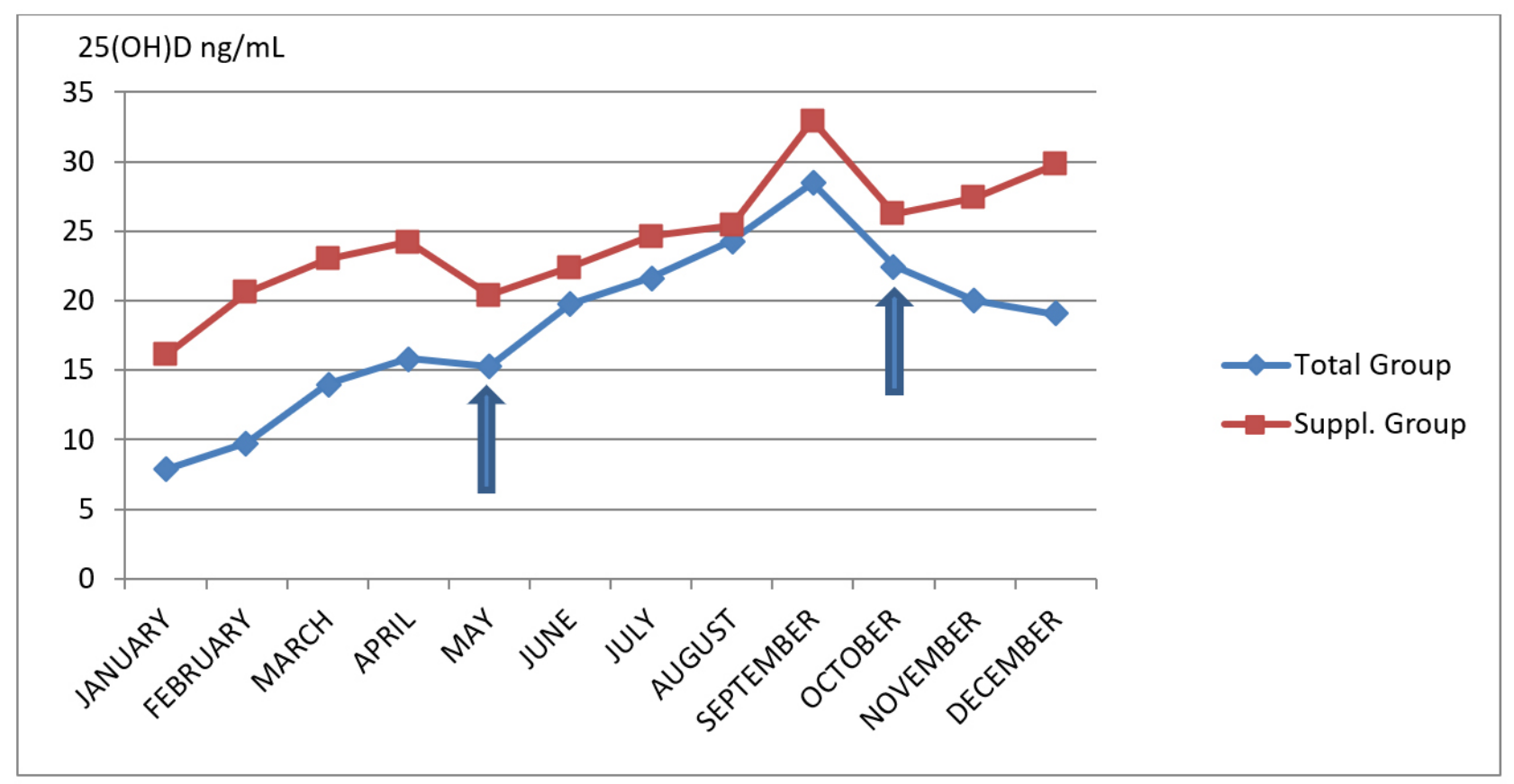

Figure Legend: The figure presents the clear benefit of supplementation therapy. Vitamin D test results of patients with prescribed supplementation had higher vitamin D levels all through the year. The graphic must be evaluated in three sections (separated with 2 arrows). Between May and October the two lines resemble a railway indicating a uniform shift in vitamin D levels in favor of supplementation. From January to April a similar appearance with a wider shift is seen indicating even a stronger effect of supplementation. In May, both lines show a sharp decline. The "May Depression" is more prominent in Supplementation Group that vitamin D median in April is not reached until August. After both lines make their peak on September, a decline is seen in October. November and December presents a clear diversion: the Supplementation Group shows an incline that can be explained by the impact of supplementation while the decline continues in the Total Group as expected in physiology of vitamin D season effect. Overall, the circannual cycle is clearly visible in Total Group neglecting the May depression. However, it is hard to call the pattern of Supplementation Group a "cycle". 
in winter; $16,7 \pm 11,3$ in spring. Two-way analyses showed a significant effect of season with a $p=0,048(p$ values $<0,05$ were considered significant) and Bonferroni test showed the single difference between spring and winter values. Istanbul is a mid-latitude city. The city lives four seasons and geographic location is quite suitable for solar vitamin D production. Winter with the highest $25(\mathrm{OH}) \mathrm{D}$ levels contradicts with the known relation between vitamin $\mathrm{D}$ production and seasons. ${ }^{(1,2)}$ Apparently, the physiologic circannual rhythm of vita- min D was disappeared in Istanbul in this study. They explained their finding due to lowest number of subjects in winter and interference between seasons because of 15 day half-life of vitamin D. Unfortunately, the study was limited with the lack of knowledge of vitamin D supplementation status of subjects. In another study, Pittaway et al. nicely presented the cyclic seasonal pattern in mean serum $25(\mathrm{OH}) \mathrm{D}$ concentrations where they followed eighty-one 60-85 year old community-dwelling adults in Tasmania over 13 consecu-

\section{5(OH)D results of both groups as median values in $\mathrm{ng} / \mathrm{mL}$.}

\begin{tabular}{|c|c|c|c|c|c|c|}
\hline & & & roup & & pplementa & iroup \\
\hline & $\mathrm{n}$ & $25(\mathrm{OH}) \mathrm{D}$ & $\% 95 \mathrm{Cl}$ & $\mathrm{n}$ & $25(\mathrm{OH}) \mathrm{D}$ & $\% 95 \mathrm{Cl}$ \\
\hline January & 5475 & 7,85 & $7,68-8,09$ & 75 & 16,06 & $14,80-17,74$ \\
\hline February & 5631 & 9,75 & $9,46-9,97$ & 102 & 20,59 & $18,04-22,51$ \\
\hline March & 4179 & 14 & $3,69-14,33$ & 80 & 22,98 & $21,21-25,77$ \\
\hline April & 3826 & 15,84 & $15,49-16,16$ & 115 & 24,21 & $22,78-27,94$ \\
\hline May & 3518 & 15,28 & $14,94-15,64$ & 117 & 20,40 & $17,91-23,33$ \\
\hline June & 3237 & 19,74 & $19,38-20,22$ & 91 & 22,38 & $18,56-26,09$ \\
\hline July & 4556 & 21,65 & $21,25-22,04$ & 123 & 24,62 & $22,22-27,28$ \\
\hline August & 3433 & 24,29 & $23,86-24,74$ & 86 & 25,40 & $23,96-29,25$ \\
\hline September & 4847 & 28,51 & $28,16-28,90$ & 66 & 32,97 & $30,12-35,50$ \\
\hline October & 5083 & 22,61 & $22,26-22,97$ & 95 & 26,25 & $23,80-27,83$ \\
\hline November & 5386 & 20,04 & 19,78-20,39 & 90 & 27,37 & $24,38-32,62$ \\
\hline December & 4801 & 19,02 & $18,65-19,34$ & 83 & 29,79 & $22,69-33,50$ \\
\hline
\end{tabular}


tive months. ${ }^{(2)}$ They also reported that for participants taking supplements, the amplitude in seasonal variation was almost completely diminished, with mean winter serum $25(\mathrm{OH}) \mathrm{D}$ concentrations very close to summer levels. This prospective study clearly presents the advers effect of vitamin D supplementation on circannual rhythm of vitamin D.

In 2015 Cong et al. reported a cross-sectional analysis of $25(\mathrm{OH}) \mathrm{D}$ levels of patients with primary hyperparathyroidism enrolled between December 2010 and February 2014 at a Northeastern U.S. latitude. ${ }^{(11)}$ Approximately two thirds of their patients were taking significant amounts of supplemental vitamin D. They reported no evidence for seasonal variability in $25(\mathrm{OH}) \mathrm{D}$ levels. They concluded this lack of seasonal variability in vitamin D levels was due, at least in part, to the high level of vitamin D supplementation. The results of their report differed from the findings of the same group performed in a similar patient cohort from the same geographic location in 1999.12 In the previous cohort, marked seasonal differences were noted in serum 25(OH)D levels, with the lowest levels seen in winter months and a linear trend in 25(OH)D levels with the highest 25(OH)D levels in September-Octo- ber. Notably, none of the participants in the prior cohort took vitamin D supplements.

Unfortunately, no season specific normal values are used worldwide nor clinicians take the physiological variations of vitamin $\mathrm{D}$ through seasons into consideration while prescribing supplementations. Supplementation therapies target a specific range without taking the season effect into account. By the way, as the rate of supplementation in a population increases the season effect should be expected to disappear. Considering the public health, what we have got here is an impact to the physiology of a strong steroid molecule with a potential effect on every single cell in the human body. We define a worldwide endemic of deficiency while there is no consensus on reference intervals and therapeutic modalities besides many other issues. Neglecting the physiological rhythm of vitamin D may have unpredictable consequences.

\section{Conflict of interest:}

This research did not receive any specific grant from funding agencies in the public, commercial, or not-forprofit sectors. 


\section{Kaynaklar}

1. Holick MF. Vitamin D: a d-lightful solution for health. J Investig Med 2011;59:872-80.

2. Pittaway JK, Ahuja KD, Beckett JM, Bird ML, Robertson IK, Ball MJ. Make vitamin D while the sun shines, take supplements when it doesn't: a longitudinal, observational study of older adults in Tasmania, Australia. PLoS One. 2013;8(3):e59063.

3. Park JE, Pichiah PTB, Cha YS. Vitamin D and Metabolic Diseases: Growing Roles of Vitamin D. J Obes Metab Syndr 2018;27:223-32.

4. Wu X, Hu W, Lu L, Zhao Y, Zhou Y, Xiao Z, et. al. Repurposing vitamin $\mathrm{D}$ for treatment of human malignancies via targeting tumor microenvironment. Acta Pharm Sin B 2019;9:203-19.

5. Heravi AS, Michos ED. Vitamin D and Calcium Supplements: Helpful, Harmful, or Neutral for Cardiovascular Risk? Methodist Debakey Cardiovasc J 2019:15:207-13.

6. Manson JE, Cook NR, Lee IM, Christen W, Bassuk SS, Mora S, et al. Vitamin D Supplements and Prevention of Cancer and Cardiovascular Disease. N Engl J Med 2019:380:33-44.
7. Prietl B, Treiber G, Pieber TR, Amrein K. Vitamin D and immune function.Nutrients 2013:5:2502-21.

8. Cefalo CMA, Conte C, Sorice GP, Moffa S, Sun VA, Cinti F, et al. Effect of Vitamin D Supplementation on Obesity-Induced Insulin Resistance: A Double-Blind, Randomized, PlaceboControlled Trial. Obesity (Silver Spring) 2018:26:651-7.

9. Aydin O. Vitamin D test results in a public hospital in midJanuary Turk J Biochem 2019;44(2):229

10. Vurgun E, Evliyaoğlu O, Vardar M. Assessment of vitamin D deficiency level by the physiological response of parathyroid hormone in Turkish adults. Turk J Biochem 2018;43:502-9.

11. Cong E, Walker MD, Kepley A, Zhang C, McMahon DJ, Silverberg SJ. Seasonal variability in vitamin D levels no longer detectable in primary hyperparathyroidism. J Clin Endocrinol Metab 2015;100:3452-9.

12. Silverberg SJ, Brown I, Bilezikian JP. Seasonal variation in 25-Hydroxyvitamin D in primary hyperparathyroidism. J Bone Miner Res 1999;14.

Alıntı Kodu: Aydın Ö. Destek tedavisi D vitamininin ylllı ritmini bozar: Retrospektif bir analiz Jour Turk Fam Phy 2020; 11 (3): 108-115. Doi: 10.15511/tjtfp.20.00308. 